\title{
Use of polypropylene ropes in concrete to minimize steel reinforcement
}

\author{
Hakim Saeed Muhammed ${ }^{1}$, Nadia Muneem Al-Abdalay ${ }^{2}$, Husein Ali Zeini ${ }^{3}$, Ahmed Hakim Saeed ${ }^{3}$ \\ ${ }^{1}$ Civil Department of Najaf Technical Institute at Alfurat Al-Awsat Technical University \\ ${ }^{2}$ Civil Department of Najaf Technical Institute at Alfurat Al-Awsat Technical University \\ ${ }^{3}$ Civil Department of Najaf Technical Institute at the Furat Al-Awsat Technical University
}

\begin{abstract}
Progress in construction and buildings industry depends on so many parameters especially materials used. Concrete materials are cheap but still need minimization in their costs. Steel is one of the materials used in concrete structural members to support the concrete as reinforcement. In this study a polypropylene rope (PP ropes) were used to support the task of steel reinforcement especially in tension zones and to decrease the total cost of the concrete section. To know how this matter achieved seven concrete beams were casted one of them was without polypropylene ropes as control beam where as others were reinforced only with polypropylene ropes. The dimensions of the concrete beams were $(200 \mathrm{~cm} \times 30 \mathrm{~cm} \times 20 \mathrm{~cm})$. Whole concrete tests were done to find out the most effective properties of concrete like compression, rupture modulus and tensile strength. Seven beams were exposed to monotonic load to find out the load at failure and corresponding deflection at mid span. Results show that if four ropes were used in tension zone of the concrete section the strength increased by about $9 \%$. This ratio seems to be low but the cheap cost of these ropes encourages designers to use a greater number of ropes in concrete section. This idea needs more future work.
\end{abstract}

Keywords: $\quad$ Deflection, splitting tensile strength, polypropylene ropes, tension zone.

Corresponding Author:

Husein Ali Zeini

Civil Department of Najaf Technical Institute at the Furat Al-Awsat Technical University

Al- Furat Al-Awsat Technical University

Address.Iraq, Najaf

E-Mail: inj.hus@atu.edu.iq.

\section{Introduction}

Concrete is considered to be a favorable material used in construction of building structural members. Since this material is composed of locally cheap constituents and has good strength properties to some extent. Efforts had been made to improve its properties. Tenths of materials were tested through using them as an admixture such as chemical materials, fibers and other additives. Improving of concrete characteristics started so many years ago by controlling the quality of its constituents to get high compressive and tensile strengths. Steel reinforcement was considered the best material that increases the efficiency of concrete sections in tension and compression. Steel is expensive so there is a need to find a cheap alternative to replace steel fully or partially. Polypropylene (PP) Ropes are the material which might help to achieve this task. They can be used as fibers or as bars. They are produced globally by so many companies and each one has its private specifications. Polypropylene (PP) is a thermoplastic "addition polymer" prepared from the grouping of propylene monomers [1]. the first two scientists who were working on Polypropylene were Paul Hogan and Robert Banks in Phillips petroleum scientist's organization in 1951. They were followed by an Italian and German scientists Natta and Rehn [1]. The commercial production of this material was started after three years of the polymerization done 
by Professor Giulio Natta (Italian chemist) in 1954. The polypropylene was widespread as a commercial production by 1957 across Europe [1]. Now this material is commonly produced all over the world [1].

\section{Characteristics of the polypropylene material}

1.No reaction with diluted acids or bases.

2.Tough material [3].

3.It retains to its original shape after releasing the effect of torsion, bending or flexing so it has good fatigue resistance [4].

4. An insulated material.

5. Cheap due to its availability.

6.Has high thermal expansion coefficient.

7.Flammable.

8. Has poor bonding.

Some of Polypropylene (PP) properties can be seen in Table 1.

Table 1. Properties of Polypropylene [2]

\begin{tabular}{|c|c|}
\hline Property & Value \\
\hline Technical Name & Polypropylene (PP) \\
\hline Melt Temperature & $130^{\circ} \mathrm{C}\left(266^{\circ} \mathrm{F}\right)$ \\
\hline Typical Injection Mold Temperature & $32-66^{\circ} \mathrm{C}\left(90-150^{\circ} \mathrm{F}\right)$ \\
\hline Heat Deflection Temperature (HDT) & $100^{\circ} \mathrm{C}\left(212^{\circ} \mathrm{F}\right)$ at $0.46 \mathrm{MPa}(66 \mathrm{PSI})$ \\
\hline Tensile Strength & $32 \mathrm{MPa}$ (4700 PSI) \\
\hline Flexural Strength & $41 \mathrm{MPa}$ (6000 PSI) \\
\hline Specific Gravity & 0.91 \\
\hline Shrink Rate & $1.5-2.0 \%(.015-.02 \mathrm{in} / \mathrm{in})$ \\
\hline
\end{tabular}

The ropes produced by Thrace Plastic Company. S.A.) [2] are designed with two Z twisted strands and have 2.0 GPa elastic modulus and $20.36 \%$ tensile elongation at failure. Polypropylene has poor cyclic loading characteristics. Lastly, prolonged exposure to the sun's ultra violet rays can cause Polypropylene fibers to disintegrate due to degradation. Polypropylene is lighter than water and can be used for floating messenger lines. Samson company which produces these ropes had a variety of such products. This American company made a manual of the mechanical, physical and chemical properties of these ropes [2]. Some of these properties can be seen in Table 2.

Table 2. Properties of PP ropes produced by Samson [3]

\begin{tabular}{|c|c|c|}
\hline PP Rope Size & Coil weight of 220 meters & Breaking Strength of Rope \\
\hline $4 \mathrm{~mm}$ & $1.63 \mathrm{~kg}$ & $214 \mathrm{kgf}$ \\
\hline $6 \mathrm{~mm}$ & $3.67 \mathrm{~kg}$ & $602 \mathrm{kgf}$ \\
\hline $8 \mathrm{~mm}$ & $6.60 \mathrm{~kg}$ & $1060 \mathrm{kgf}$ \\
\hline $10 \mathrm{~mm}$ & $10.00 \mathrm{~kg}$ & $1560 \mathrm{kgf}$ \\
\hline $12 \mathrm{~mm}$ & $14.50 \mathrm{~kg}$ & $2210 \mathrm{kgf}$ \\
\hline $14 \mathrm{~mm}$ & $20.00 \mathrm{~kg}$ & $3050 \mathrm{kgf}$ \\
\hline $16 \mathrm{~mm}$ & $25.50 \mathrm{~kg}$ & $3770 \mathrm{kgf}$ \\
\hline $18 \mathrm{~mm}$ & $32.50 \mathrm{~kg}$ & 4810 \\
\hline
\end{tabular}

\section{Experimental work}


The experimental work comprises the following:

1. Materials used and tests achieved to conform standard specifications.

2. Tests on polypropylene ropes.

3. Steel molds.

4. Concrete tests.

5. Beam tests.

\subsection{Materials used}

\subsubsection{Cement}

An ordinary Portland cement named AL-Kar (Type I) produced in Najaf Province - Middle region of Iraq was used during this investigate. It was stored in suitable state to avoid any strange risky situations. The results of the chemical and physical indicate that the cement conformed to specification (No.5/1984) [4]. They are shown in Tables 3 and 4 respectively.

Table 3. Chemical composition of cement

\begin{tabular}{|c|c|c|}
\hline Oxides Composition & Content \% & Limits of Iraqi Specification No.5/1984[4] \\
\hline $\mathrm{CaO}$ & 56 & -ב-בי \\
\hline $\mathrm{SiO}_{2}$ & 19 & - \\
\hline $\mathrm{Al}_{2} \mathrm{O}_{3}$ & 3.98 & 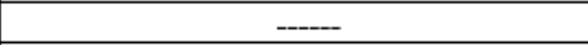 \\
\hline $\mathrm{Fe}_{2} \mathrm{O}_{3}$ & 3.76 & $-\cdots$ \\
\hline MgO & 2.79 & $<5.00$ \\
\hline $\mathrm{SO}_{3}$ & 2.32 & $<2.80$ \\
\hline L.O.I & 3.04 & $<4.00$ \\
\hline I.R & 1.01 & $<1.5$ \\
\hline L.S.F & 0.962 & $0.66-1.02$ \\
\hline $\mathrm{C}_{3} \mathrm{~A}$ & 4.187 & ב-ב-ב-ב \\
\hline $\mathrm{C}_{3} \mathrm{~S}$ & 57.04 & 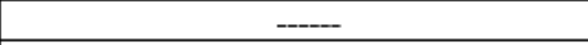 \\
\hline $\mathrm{C}_{2} \mathrm{~S}$ & 14.83 & ב-ב-בי \\
\hline $\mathrm{C}_{4} \mathbf{A F}$ & 10.95 & 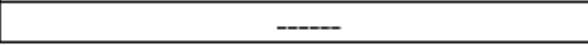 \\
\hline
\end{tabular}

Table 4. Physical properties of cement

\begin{tabular}{|c|c|c|}
\hline Physical Properties & $\begin{array}{c}\text { Test } \\
\text { Results }\end{array}$ & $\begin{array}{l}\text { Limits of Iraqi Specification } \\
\text { No.5/1984[4] }\end{array}$ \\
\hline Specific Surface Area (Blaine Method), $\mathrm{m}^{2} / \mathrm{kg}$ & 483 & $\geq 230$ \\
\hline Setting Time (Vicat Apparatus), & & $\geq 00: 45$ \\
Initial Setting, hr.: min & $2: 50$ & $\leq 10: 00$ \\
Final Setting, hr. : min & $4: 30$ & \\
\hline Compressive Strength, $\mathrm{MPa}$ & & $\geq 15.00$ \\
3 days & 31.60 & $\geq 23.00$ \\
\hline 7 days & 38.70 & $\leq 0.8$ \\
\hline Soundness (Autoclave Method),\% & 0.25 & \\
\hline
\end{tabular}

\subsubsection{Aggregates}

Natural sand from Bahr AL-Najaf was utilized for production a concrete mixes of this investigate. A river coarse aggregate was brought from east of Iraq called Bedra position. The aggregates was washed carefully and tested. The consequences of the grading of fine and coarse aggregates are conformed to Iraqi Specifications No.45 1984 [5] and the consequences of grading tests can be shown in Tables 5 and 6 respectively.

Table 5. Grading of fine aggregate 


\begin{tabular}{|c|c|c|}
\hline $\begin{array}{c}\text { Sieve Size } \\
(\mathbf{m m})\end{array}$ & $\begin{array}{c}\text { Cumulative Passing } \\
\%\end{array}$ & $\begin{array}{c}\text { Cumulative Passing \% } \\
\text { Limits of Iraqi Specifications No.45 - } \\
\text { 1984 } \\
\text { Fine Aggregate-zone (4) }\end{array}$ \\
\hline 4.75 & 100 & $95-100$ \\
\hline 2.36 & 100 & $95-100$ \\
\hline 1.18 & 100 & $90-100$ \\
\hline 0.60 & 100 & $80-100$ \\
\hline 0.30 & 50 & $15-50$ \\
\hline 0.15 & 10 & $0-15$ \\
\hline & & \\
\hline
\end{tabular}

Table 6. Grading of gravel compared with Iraqi Specification No. 45-1984[5]

\begin{tabular}{|c|c|c|}
\hline \multirow{2}{*}{ Sieve size } & Allowable Percentage ratio passing through sieves & \multirow{2}{*}{ Current Agg. sample } \\
\cline { 2 - 3 } & Nominal size of aggregate is(5-20) mm & 100 \\
\hline $37.5 \mathrm{~mm}$ & 100 & 98 \\
\hline $20 \mathrm{~mm}$ & $95-100$ & 92 \\
\hline $14 \mathrm{~mm}$ & - & 70 \\
\hline $10 \mathrm{~mm}$ & $30-60$ & 8 \\
\hline $5 \mathrm{~mm}$ & $0-10$ & - \\
\hline $2.36 \mathrm{~mm}$ & - & \\
\hline
\end{tabular}

\subsubsection{Polypropylene ropes}

The selected samples of polypropylene ropes were taken from ten independent coils. They are $10 \mathrm{~m}$ in length each sample. They were tested to see the average weight of them and they were exposed to breaking strength test to know if it is capable of carrying applied loads and their conformation to a standard specification. The average weight for whole selected samples was $1155 \mathrm{gm} / 10 \mathrm{~m}$ rope length and the average breaking strength of ropes was $3500 \mathrm{~kg}$. These results were conformed with the specifications of Samson Ropes Company [2].

\subsection{Steel molds and concrete mixes}

A $(200 \mathrm{~cm} \times 30 \mathrm{~cm} \times 20 \mathrm{~cm})$ steel molds were fabricated to be used in beams to cast concrete beams of the work. A mix design was done to reach concrete compression strength of about $25 \mathrm{MPa}$. The materials ratio used was 400kg cement: $792 \mathrm{~kg}$ fine aggregate: $961 \mathrm{~kg}$ coarse aggregates mixed with $202 \mathrm{~kg}$ of water. Seven molds were casted giving symbol $\mathrm{S}$ starting with $\mathrm{S}_{1}$ which represents control beam (beam without polypropylene ropes). Other six beams were casted to see the effect of using polypropylene ropes and what can this cheap material supports and helps concrete in compression and tension besides the minimization of steel bars quantity. Four polypropylene ropes were used in the lower layer of concrete in the mold and two ropes in the upper layer. No stirrups were used to study purely the flexural strength of beams as shown in plate 1 . The study of shear was not taken into consideration in this paper.
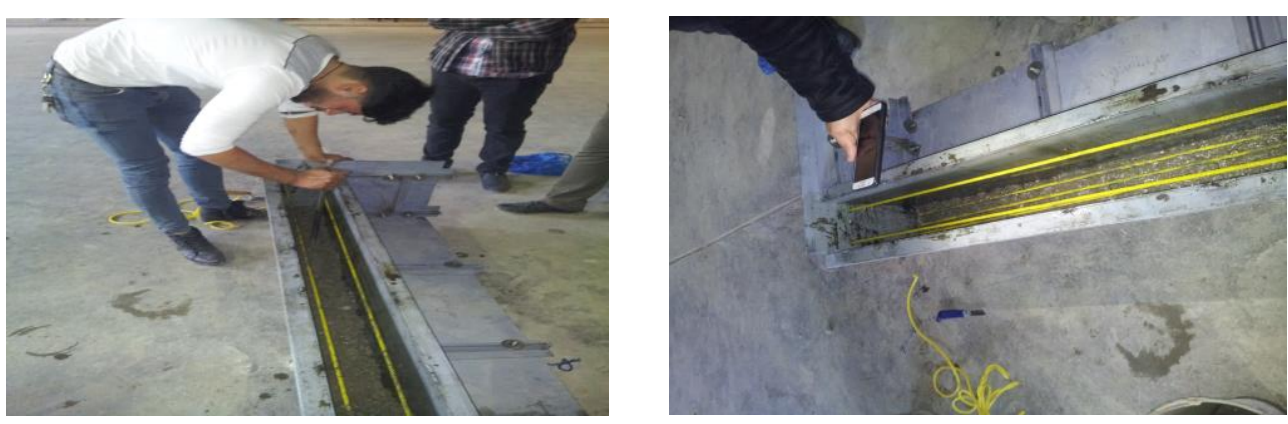

\subsection{Concrete tests}

Plate 1. Steel mold used and concrete casting process 
A samples of concrete were taken to cast $(100 \mathrm{~mm} \times 200 \mathrm{~mm})$ cylindrical shape specimens to be utilized in finding compressive strength of concrete according to ASTM C39-86 [6]. These samples and according to ASTM C496-86 specification [7] were used to find the Strength under Splitting Tension. Beam prisms $(100 \mathrm{~mm} \times 100 \mathrm{~mm} \times 400 \mathrm{~mm})$ were ready according to ASTM C192-88[5] and were tested according to the ASTM C78-84specification [6] to find flexural strength of concrete.

\subsubsection{Beam tests}

The beams were tested utilizing the calibrated electro hydraulic universal testing machine with maximum range capability of $2000 \mathrm{KN}$. A two points loading mechanism was used to test all beams. The dial gage was fixed in its marked location to touch the center of bottom beam, in order to be certain that the dial plungers had touched the center of beam surface. Loading was ongoing by applying single point load into a platform which was equally separated into two point loads transferred to the concrete beam see Fig. 1 and plate 2. The load magnitude for each load step was kept constant in the increments. At each load step, concrete surface strains and the dial gage readings were noted. This procedure was continued till the cracks appeared.

The cracks were noticeable on the beam surface and the load magnitude at these cracks was registered. The flexure cracking load was described as the load at the time when the critical flexure crack crossed the mid -depth of the beam as shown in plate 3. The failure load was recorded when an increase in deformation was noticed with consequent drop in load.

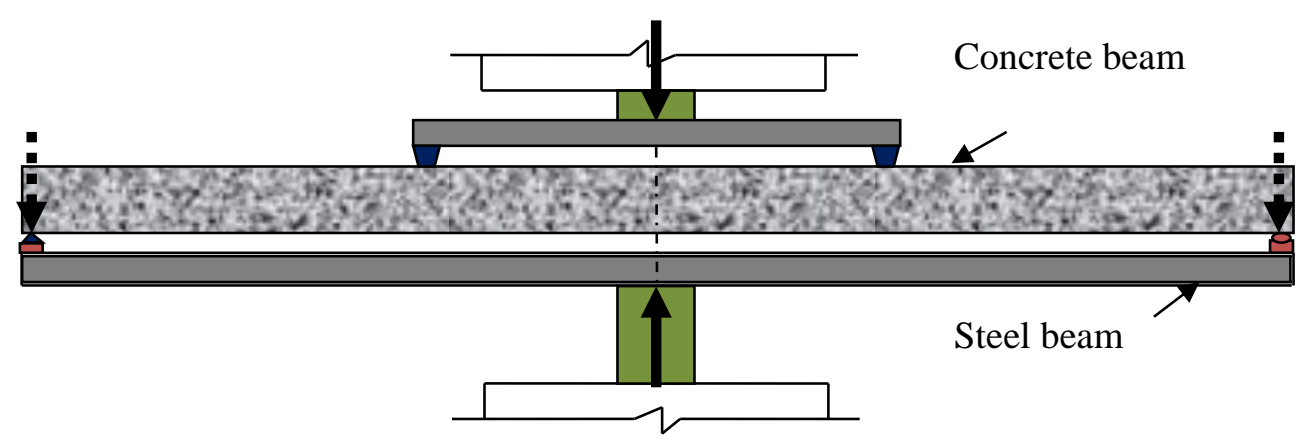

Figure 1. Schematic elevation of Beam Testing

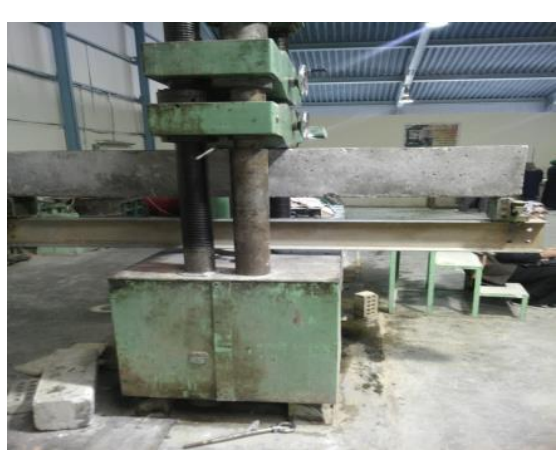

Plate 2. Beam testing
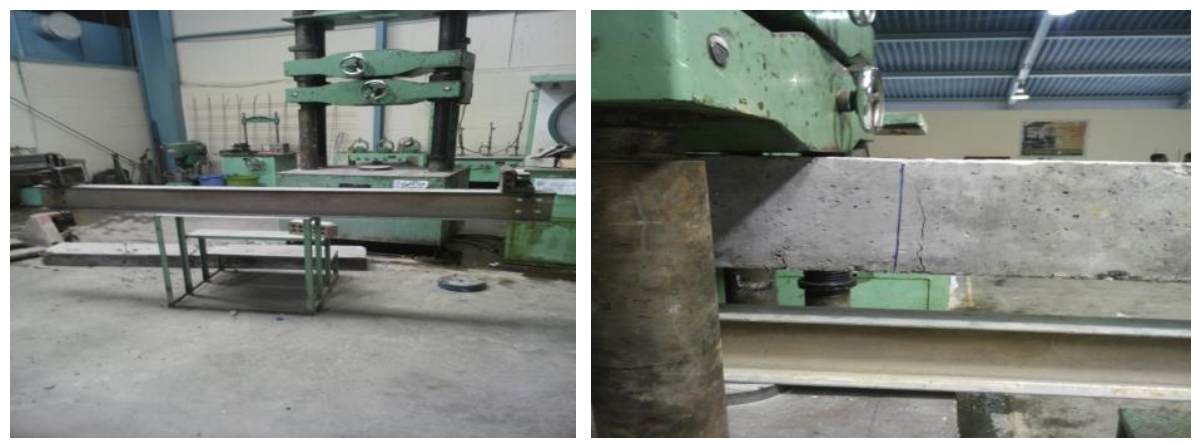

Plate 3. Beam flexural cracks

\subsubsection{Analysis of the concrete section}

\subsubsection{When only PP ropes were used in tension zone}

Fig.2 shows a rectangular concrete section and reinforced by PP ropes in the lower middle half of a certain simply supported beam. By simple mathematical operations, the following formula can be governed: 


$$
x=\frac{1}{1+\left(\frac{\sigma_{p p}}{\sigma_{c} \cdot m}\right)} \cdot d=k \cdot d
$$

$x$ is the upper fiber distance of the section from the neutral axis, $\sigma_{p p}$-allowable stress in $p p$ ropes area. $\sigma_{c}-$ allowable stress in concrete. $m$-modular ratio $=E_{P P} / E_{c}$. $d$-effective depth of the section, $K$-neutral axis

constant $=\frac{1}{1+\left(\frac{\sigma p p}{\sigma_{c} \cdot m}\right)}$

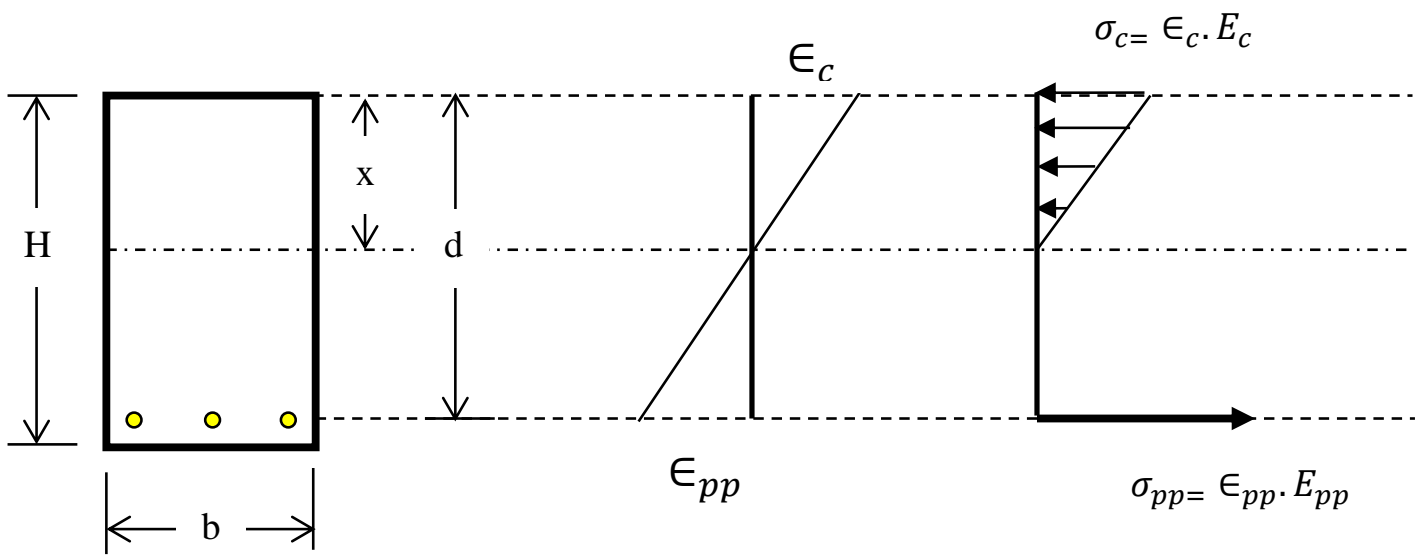

Figure 2. Stresses and strains induced in rectangular concrete section

$\epsilon_{p p}$ is the strain in pp ropes. $E_{p p}$ is modulus of elasticity of $p p$ ropes. $\varepsilon_{c}$ is strain in concrete and $E_{c}$ is concrete the modulus of elasticity.

The developed maximum moment induced in the section is resisted by the compression in concrete whereas tension is resisted by polypropylene ropes and concrete is assumed to resist only compression (tension is ignored). The neutral axis passes through the centre of gravity of the composite section which includes concrete and polypropylene ropes. The formula mentioned is for the position of neutral axis determination when the stresses induced in the section are given. When the geometric shape of the section and area of reinforcement are given, the position of neutral axis is $y$ :

$$
x=\frac{-m \cdot A_{p p} \pm \sqrt{\left(m \cdot A_{p p}\right)^{2}+2 m \cdot A_{p p} \cdot b \cdot d}}{b}
$$

Where $A_{P P}$ is the area of pp ropes and $\mathrm{b}$ is the breadth of the concrete section. The moment of resistance MR of a balanced section can be calculated from the couple of forces shown in Fig. 3.

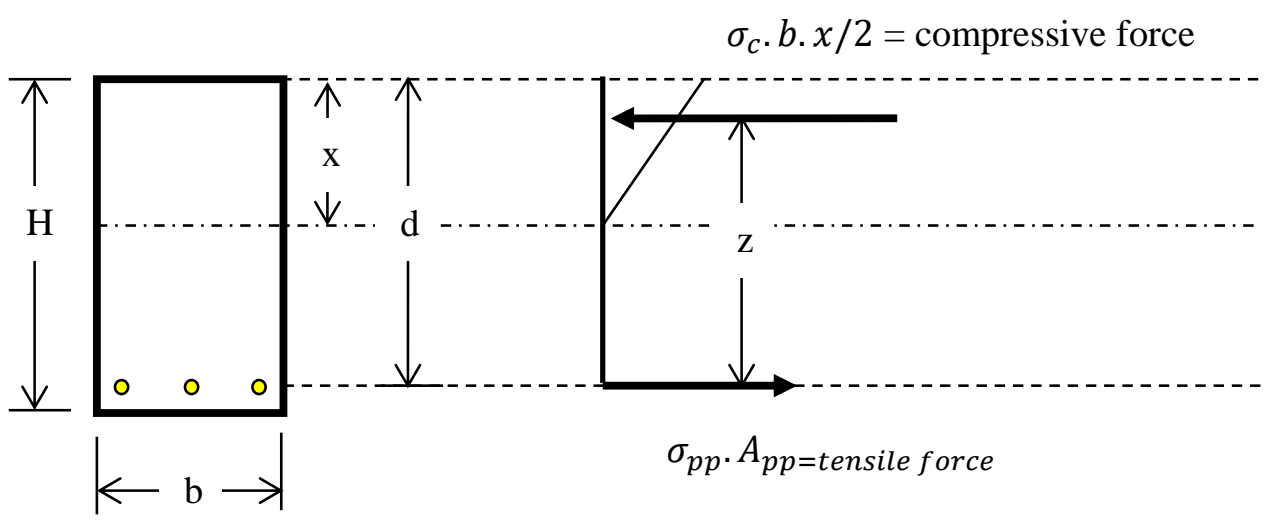

Figure 3. Couple forces induced in rectangular concrete section.

$\mathrm{Z}=\mathrm{d}-(x / 3)=\mathrm{d}-(k d / 3)=(1-k / 3) d=j d$ 
$M R=\sigma_{c} \cdot b \cdot \frac{x}{2} * Z=\sigma_{c} \cdot b \cdot \frac{x}{2} * j d=\frac{1}{2} k j \sigma_{c} \cdot b d^{2}=Q b d^{2}$

$Q$ is called moment of resistance constant $=\frac{1}{2} k j \sigma_{c}$

The moment of resistance alternatively can be evaluated from tension zone as follows:

$\sigma_{p p} \cdot A_{p p} j \cdot d=Q \cdot b d^{2}$

From which

$$
A_{p p .}=\frac{\sigma_{c} \cdot b d}{2 \sigma_{p p}} \cdot k
$$

The above equation can be used to find out the area of pp ropes reinforcement and by the same way it can be evaluated for under and over reinforced sections. A hint must be mentioned here that the assumptions of the ACI code to compute nominal flexural strength are based on satisfying the applicable conditions of equilibrium and compatibility stress. In addition to that strains in the reinforcement and in the concrete shall be expected directly relative to the distance from the neutral axis. The maximum usable strain at the extreme concrete compression fiber shall be assumed equal to 0.003. A study must be done to know that if these requirements are applicable in using only PP ropes, otherwise new recommendations should be drawn in studying the use of PP ropes only.

\subsubsection{When in addition of PP ropes a steel reinforcement were used in tension zone}

The rectangular section shown in Fig. 4 is reinforced by two types of reinforcement pp ropes and steel. Moment of resistance is also given by for the compression zone:

$M R=Q b d^{2}$

But moment of resistance from tension zone is different now and it will be given by:

$M R=\left[\sigma_{p p} \cdot A_{p p}+\sigma_{s} \cdot A_{s}\right] j d=Q b d^{2}$

From which $\quad \sigma_{p p} \cdot A_{p p}+\sigma_{s} \cdot A_{s}=\frac{M R}{\left(1-\frac{k}{3}\right) \cdot d}$

$\mathrm{K}$ is calculated from an equation given before and it depends on the stresses induced in pp ropes and concrete because pp ropes has not the ability to withstand strains compared to steel reinforcement and it will fail before it.

$$
\sigma_{c} \cdot b \cdot \frac{x}{2}=\text { compressive force }
$$

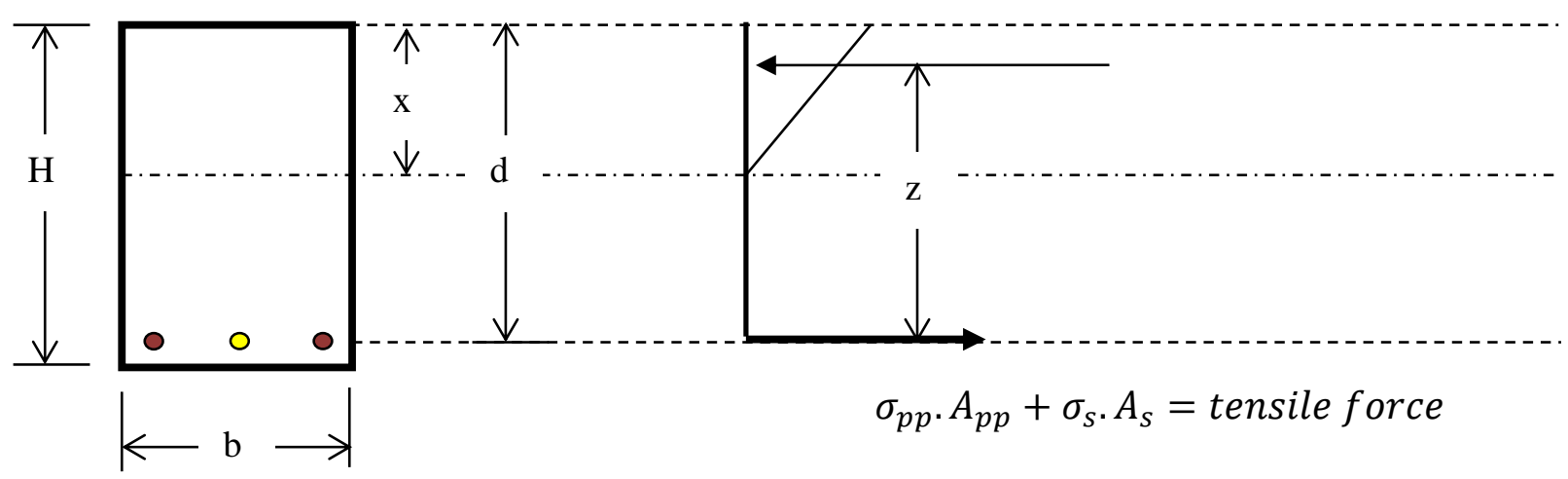

Figure 4. Couple forces induced in rectangular concrete section reinforced by pp ropes and steel 
The area of pp ropes needed to help and support steel reinforcement to carry tension stresses can be calculated from Eq. (3) when area of steel is given and pp ropes engineering properties are known.

\section{Results and discussion}

The consequences of tests conducted on the control specimen and other beams are summarized in Table 3 and Table 4.

\subsection{Strength in compression}

According to ASTM C39-86 [6] the samples were tested in compression. A cylindrical specimen $(100 \mathrm{~mm} \times 200 \mathrm{~mm})$ in 28 days' age were used to find out compressive strength of Concrete using compression testing machine.

\subsection{Strength under splitting tensile}

$(100 \mathrm{~mm} \times 200 \mathrm{~mm})$ cylinders' specimen were prepared according to the ASTM C496-86 specification [7]. strength under splitting tensile values were considered with following expression:

$$
\text { fspf }=\frac{2 p}{\Pi d l}
$$

$\mathrm{fspf}=$ Strength under splitting tensile $(\mathrm{MPa}), \mathrm{P}=$ Maximum applied load $(\mathrm{N}), \mathrm{d}=$ Specimen diameter in $\mathrm{mm}$ and $\mathrm{L}=$ Specimen length in $\mathrm{mm}$.

\subsection{Rupture modulus}

A concrete prism of $(100 \times \mathrm{mm} \times 100 \mathrm{~mm} \times 400 \mathrm{~mm})$ in dimensions were prepared in accordance with ASTM C192-88 specification [8]. The rupture modulus of concrete is specified by a use of $600 \mathrm{KN}$ capability machine. Prisms were tested by using the two points load with a $300 \mathrm{~mm}$ clear span to fulfill the ASTM specification [9]. According to the formula (6) the modulus of rupture can be calculated.

$$
\operatorname{frf}=\frac{P L}{b h 2}
$$

frf $=$ rupture modulus in $(\mathrm{MPa}), \mathrm{P}=$ applied load $(\mathrm{N}), \mathrm{b}=$ specimen width $(\mathrm{mm})$ and $\mathrm{h}=$ specimen depth $(\mathrm{mm})$.

\subsection{Modulus of elasticity (static)}

ASTM, C469- 87a [10] states that 40\% of ultimate compressive strength is applied on the concrete cylinders to achieve Static modulus of elasticity of concrete utilizing the following expression :-

$\mathrm{E}=[(\mathrm{S} 2-\mathrm{S} 1) /(\mathrm{e} 2-0.00005)] \times 10^{-3}$

$\mathrm{E}=$ static modulus of elasticity in GPa

$\mathrm{S} 1=$ stress corresponding to a longitudinal strain (0.00005) in MPa .

$\mathrm{S} 2=$ stress corresponding to $40 \%$ of ultimate load in $\mathrm{MPa}$.

e2 = longitudinal strain produced by stress $\mathrm{S} 2$.

Table 3. Properties of hardened concrete

\begin{tabular}{|c|c|c|c|}
\hline $\begin{array}{c}\text { Sample } \\
\text { No. }\end{array}$ & $\begin{array}{c}\text { Compressive } \\
\text { Strength f'c (MPa) }\end{array}$ & $\begin{array}{c}\text { Strength under splitting } \\
\text { tensile } \\
\text { Fsp (MPa) }\end{array}$ & $\begin{array}{c}\text { Modulus } \\
\text { Of Rupture } \\
\text { Fr (MPa) }\end{array}$ \\
\hline $\mathrm{S}_{1}$ (Control batch) & 29.4 & 4.6 & 3.2 \\
\hline $\mathrm{S}_{2}$ & 28.9 & 4.2 & 4.2 \\
\hline $\mathrm{S}_{3}$ & 27.8 & 3.9 & 4.6 \\
\hline $\mathrm{S}_{4}$ & 29.0 & 4.4 & 3.9 \\
\hline $\mathrm{S}_{5}$ & 26.8 & 5.1 & 4.1 \\
\hline $\mathrm{S}_{6}$ & 27.9 & 4.9 & 4.4 \\
\hline
\end{tabular}


PEN Vol. 7, No. 4, December 2019, pp.1904- 1914

\begin{tabular}{|c|c|c|c|}
\hline $\begin{array}{c}\text { Sample } \\
\text { No. }\end{array}$ & $\begin{array}{c}\text { Compressive } \\
\text { Strength f'c (MPa) }\end{array}$ & $\begin{array}{c}\text { Strength under splitting } \\
\text { tensile } \\
\text { Fsp (MPa) }\end{array}$ & $\begin{array}{c}\text { Modulus } \\
\text { Of Rupture } \\
\text { Fr }(\mathrm{MPa})\end{array}$ \\
\hline $\mathrm{S}_{7}$ & 28.7 & 4.8 & 3.8 \\
\hline
\end{tabular}

Table 4. Loads applied with deflection at mid span

\begin{tabular}{|c|c|c|c|c|c|}
\hline $\begin{array}{c}\text { Load } \\
\text { applied } \\
\text { in (kg) }\end{array}$ & $\begin{array}{c}\text { Deflection in } \\
\text { mm for beams } \\
\text { with } \\
\text { polypropylene } \\
\text { ropes }\end{array}$ & $\begin{array}{c}\text { Deflection in } \\
\text { mm for beams } \\
\text { without } \\
\text { polypropylene } \\
\text { ropes }\end{array}$ & $\begin{array}{c}\text { Load } \\
\text { applied } \\
\text { in (kg) }\end{array}$ & $\begin{array}{c}\text { Deflection in } \\
\text { mm for beams } \\
\text { with } \\
\text { polypropylene } \\
\text { ropes }\end{array}$ & $\begin{array}{c}\text { Deflection in mm } \\
\text { for beams } \\
\text { without } \\
\text { polypropylene } \\
\text { ropes }\end{array}$ \\
\hline 100 & 0.02 & 0.04 & 1600 & 1.3 & 1.42 \\
\hline 200 & 0.03 & 0.06 & 1700 & 1.34 & 1.48 \\
\hline 300 & 0.06 & 0.08 & 1800 & 1.38 & 1.53 \\
\hline 400 & 0.1 & 0.17 & 1900 & 1.41 & 1.64 \\
\hline 500 & 0.4 & 0.5 & 2000 & 1.43 & 2.99 \\
\hline 600 & 0.8 & 0.9 & 2100 & 1.47 & \\
\hline 700 & 1 & 1.08 & 2200 & 1.5 & \\
\hline 800 & 1.06 & 1.1 & 2300 & 1.55 & \\
\hline 900 & 1.07 & 1.15 & 2400 & 1.58 & \\
\hline 1000 & 1.1 & 1.18 & 2500 & 1.6 & \\
\hline 1100 & 1.17 & 1.2 & 2600 & 1.66 & \\
\hline 1200 & 1.18 & 1.25 & 2700 & 1.7 & \\
\hline 1300 & 1.2 & 1.28 & 2800 & 1.75 & \\
\hline 1400 & 1.24 & 1.32 & 2900 & 1.90 & \\
\hline 1500 & 1.26 & 1.39 & 3000 & 2.40 & \\
\hline
\end{tabular}

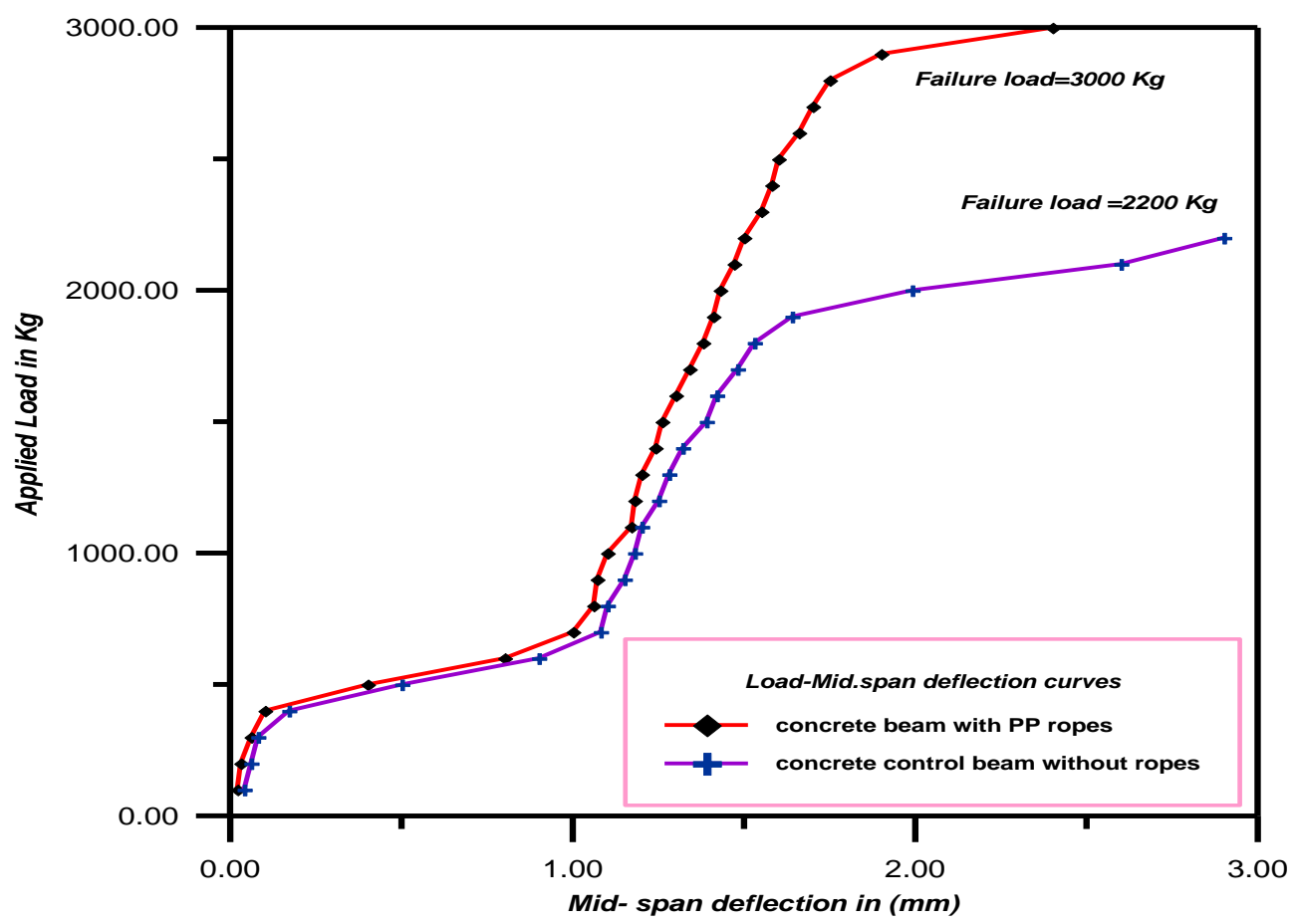

Figure 5. Results of the tested beams (with and without polypropylene ropes) 
Figure 5 shows the results of the applied loads and corresponding deflections. It is visibly appeared from this figure that the usage of PP ropes improved the capacity of the concrete section to $3000 \mathrm{~kg}$ compared to $2200 \mathrm{~kg}$ for section without ropes. In addition, the deflection is minimized to $2.4 \mathrm{~mm}$ compared to $2.9 \mathrm{~mm}$. If the number of ropes increased the capacity is also increased with the help of steel reinforcement.

During the process of PP ropes tests it was noticed that the ropes extended quickly and rapidly till the breaking. That means the material is highly elastic and the concrete under loads extends without capturing extension by this reinforcement. This phenomenon appears clearly when testing beams. The shape of beam failure was flexural fracture accompanied with a growth of vertical cracks in concrete, start from down fibers to the upper face of the beam. Concrete failed before ropes and this means that this material cannot be used alone without steel reinforcement. It can help steel reinforcement to some extent. The use of four PP ropes in the present study raised the capacity of concrete section in tension zone by about $9 \%$. If the number of ropes increased the capacity of the section is expected to be more and that needs more study.

\section{Conclusions and recommendations}

The following decisions and recommendations can be recorded in this study as:

1. Bond between ropes and concrete is weak, so this property needs study through testing many beams by push-off and pull-out tests.

2. Studying the phenomena of bond experimentally and theoretically leads to an accurate design steps of this new use of ropes in concrete.

3. An effort must be achieved in studying concrete beams of PP ropes in different ages extended to one or two years.

4. Using PP ropes alone in concrete is prohibited because failure starts in concrete before ropes, so sudden failure may occur.

5. The compatibility between concrete and ropes must be studied carefully in so many parameters especially coefficient of thermal expansion.

6. The degradation in ropes strength due to exposure to UV rays is not found in concrete members because ropes are buried in the concrete.

7. According to my opinion PP ropes are not used with concrete by this way ago elsewhere (depending upon the so many producers of this material who are using their manufacturing products properties). There will not be an international or national code used as a standard guide. This means that an independent code must be prepared throughout concentrated efforts and studies.

\section{Acknowledgment}

The authors gratefully acknowledge the staff of Concrete Laboratory in Civil Department of Najaf Technical Institute for their support.

\section{References}

[1] https:www.creativemechanisms.com

[2] http://www.thracegroup.com/tr/en/companies/thrace-plastics/

[3] Samson Ropes Company. Rope user's manual, Guide to rope selection, handling, Inspection and retirement, 2090 Thornton Street, Ferndale, WA 98248.

[4] Iraqi standard specifications, No.5/1984., "Portland cement".

[5] Iraqi standard specifications, No.45/1984., "Fine and coarse aggregates". 
[6] ASTM C39-86, "Standard Test Method for Compressive Strength of Cylindrical Test Specimens", Annual Book of Standard American Society for Testing and Materials, Vol.04.02, 2003.

[7] ASTM C 496-86, "Standard Test Method for Splitting Tensile Strength of Cylindrical Concrete Specimens", Annual Book of ASTM Standards, Vol. 04.02, pp.259-262, 2003.

[8] ASTM C192-88, "Standard Practice for Making and Curing Concrete Test Specimens in the Laboratory", Annual Book of ASTM Standard, Vol. 04.02, 2003.

[9] ASTM C78-84, "Standard Test Method for Flexural Strength of Concrete (Using Simple Beam with Two Points Loading", Annual Book of ASTM Standard, Vol. 04.02, 2003.

[10] ASTM C469-87a, "Standard Test Method for Static Modulus of Elasticity and Poisson's Ratio of Concrete in Compression", Annual Book of ASTM Standards, Vol. 04-02, 1989, PP.236-289. 